\title{
TRENDS AND PROBLEMS IN THE SOCIOLOGICAL STUDY OF CRIME*
}

\author{
STANTON WHEELER
}

Yale University

\begin{abstract}
Major trends in the sociological study of crime for the past quarter of a century include a movement away from concrete studies of crime and criminals toward more general theories of deviance and social control, the development of labeling theory as a dominant perspective in sociology, a concentration on applied, "impact" studies, and the growth of conflict theory. One consequence of these trends is that we have withdrawn attention from the offender to those who are part of the social control network. A need to refocus our attention on the nature of criminal activity is suggested. Second, we should devote more resources to the study of so-called "white-collar crime." Our failure to do so is documented, along with reasons for the failure and suggestions for some directions such studies might take.
\end{abstract}

The theme of these meetings is "The Way We Were," and implicitly, the way we are, and what we might become. I wish to address these issues as they apply to that domain of social problems known as the study of crime. I do not propose to review the field, noting gains and losses, pluses and minuses, as one might for a chapter of a handbook. Rather, I should like to try to sustain a thesis, an argument, about our understanding of crime.

Over the past quarter of a century, the concepts we have used to comprehend crime and criminality, and the research we have conducted, have changed. These changes have had two crucial consequences. First, they have led us to focus on those agents and agencies that deal with offenders: the police, the courts, and other way stations in our system of social control. In the course of this shift, we have been led away from our original point of inquiry, namely, crime, the criminal, and criminality. The result is that we now know far more about those persons whose jobs depend on the existence and importance of crime, than we do about the offenders.

Second, and even more important, in one particular area of criminality, we have been almost totally negligent. I refer to the patterns of illegal activity that lie at the core of large-scale corporate, industrial society. Our neglect is not only a result of narrowness of vision, it is a neglect that emerges for good sociological reasons. But it is nonetheless neglect. If we project ahead rather than being dominated by the present, we can anticipate that it is precisely in this area where the most interesting and in many ways most crucial aspects of crime will be found. An important challenge, therefore, is to find ways to examine in depth the patterns of illegal activity that will become the routine forms of illegality in a postindustrial, educated, affluent, heavily bureaucratized, and perhaps over-regulated society.

To document this thesis fully and in detail would require a book rather than a short article. I shall therefore try to stick to essentials. Let me begin about the time that SSSP was being formed, in the late 1940s and early 1950s. At that

* Presidential address delivered at the 24th annual meeting of the Society for the Study of Social Problems, San Francisco, August, 1975 
time our understanding of crime and criminality was based heavily on a remarkable series of studies conducted in Chicago prior to World War II by persons, many of whom had been influenced in one way or another by Robert E. Park or Ernest Watson Burgess. The studies were basically descriptive, some statistical, some ethnographic. They told us much about the nature of delinquency and crime in the Chicago of that day. Indeed, I need hardly remind this audience of The Gang (Thrasher, 1927), The Natural History of a Delinquent Career (Shaw, 1931), and The Professional Thief (Sutherland, 1937).

But sociology after the war was in the midst of change, and so, too, the study of crime. Four changes seem most crucial: First, the move during the 1950s toward a more explicitly analytical and theoretical sociology of deviance; second, throughout the decade of the 60 s and into the early $70 \mathrm{~s}$, our love affair with labeling theory; third, as a result of the enormously increased funding by federal agencies, the burgeoning of applied research, particularly evaluation studies; and fourth, over much of the last decade, the rediscovery of Marx and conflict theory and a searching of its relevance for the study of crime.

Each of these changes has brought something new and valuable to our understanding, advances that a full assessment would review in some detail. But I want to note the costs we have incurred while gaining those advances. The shift from the descriptive to the explicitly and avowedly theoretical during the $1950 \mathrm{~s}$ helped to enrich sociology generally and made the field of deviance one of the most exciting domains within sociology. But it also, and unhappily, helped cut off the flow of rich ethnographic accounts of the nature, structure, and organization of the activity in question.

In our concern for labeling theory, we turned an important insight into a dominant perspective, and though still filled with controversy and lacking definitive tests of the precise effects of labeling, there has been a real advance in our understanding, especially in areas where definitions of deviance are vague. But an important cost is that we shifted our attention from the delinquent or criminal, who now became merely a person so labeled, to those who were doing the dirty work: police, judges, and other official agents. Intellectual resources are scarce, and as they turned to the reaction system, they necessarily withdrew from a really deep probing of crime and criminal activity itself. Now this is not to say that aspects of labeling are uninvolved in our understanding of crime. Surely they are. But the amount of insight we get from the concept of labeling seems to me to diminish greatly as we move from delinquency or mental illness, say, to arson, bank robbery, or highjacking. And our understanding of these phenomena, indeed even the incentive to engage in inquiries regarding them, were blunted by our concern for societal reaction.

The enormous growth of applied research on crime, particularly the hundreds of evaluation studies, make up a large proportion of all the research devoted to crime-related problems over the last fifteen years. The impetus has been more immediate and practical, and in some instances there appear to have been real consequences. For example, one consequence of all those studies that demonstrate again and again that we do not know how to treat, rehabilitate, change, alter, or modify the behavior of offenders has surely been to hasten the demise of the treatment and rehabilitative ideology as a justification for incarceration (von Hirsch, 1976). But the vast bulk of this work is undertaken in behalf of the criminal justice system after the offender is already in its arms. Only rarely are there efforts to study the offender in the field as he is situationally induced 
toward or away from a criminal act. Furthermore, the organization of funding has led to an emphasis on law enforcement as traditionally defined. It has reinforced our tendency to look at the police and the criminal courts, rather than, for example, the SEC, the IRS, or the anti-trust division of the Justice Department.

The emergence of conflict theory and the rediscovery of Marx may perhaps move us in a new direction. Surely those who write in this tradition feel it will, for they speak of the Social Reality of Crime (Quinney, 1970), and The New Criminology (Taylor, Walton, Young, 1973), a more politically aware and politically sensitive treatment of the subject of crime and deviance. It is too early now to judge the fruits of these latest conceptions, but it is my strong impression that the achievements have been more rhetorical than anything else, that whatever their value in changing our conception of crime, they have not led to new and fresh empirical inquiry. And that is a shame, for it is precisely from this tradition that we might have expected an emphasis, not only on crime and illegality among the powerful, but also on those agencies of social control that regulate the well-to-do rather than the poor, the corporation rather than the individual, the official rather than his subjects.

So how improved is our basic understanding of crime and criminality now relative to a quarter of a century ago? I draw two conclusions, the first concerning traditional forms of crime, or what have been called "normal crimes," and the second concerning less traditional forms of illegality. With respect to the first, my judgment is that we have advanced very little. Relative to the greatly increased expenditures of resources for research on crime and delinquency, and the amount of attention devoted specifically to the criminal justice system, our basic knowledge about criminal activity is blunted and shallow. To be sure, there are exceptions: a continual flow of work on delinquency of a variety of kind, including gang studies, survey research efforts, and occasional statistical or quantitative studies of particular relevance to policy, such as the Wolfgang, Figlio, and Sellin Cohort Study (1972). But apart from these, we have only a smattering: a statistical study of rape, a biographical account of a longtime burglar, a study or two of hustling, some quantitative and demorgraphic data on homicide, some interesting work on organized crime, and importantly, the new victimization studies." But where are the studies of criminal activity that ought to be occupying the shelves along with these? What we do we really know, in a systematic fashion, about burglary, arson, or auto theft, to cite only three examples. A fascinating recent book like Carl Klockars' The Professional Fence, (1974), a life-history document, is conspicuous because it sits there so alone. ${ }^{2}$

This general view is confirmed, at least for me, by examining the texts that are most clearly oriented toward types of crime. Their authors have presumably surveyed the literature and have included the most relevant data and findings on property offenders, sex offenders, professional offenders, and the like. Almost

1 This paper is not intended as a review of the literature, and I am sure others might have a working list of monographs they deem significant which is perhaps two or three times as long as mine. The main point is that apart from delinquency, there are probably not more than two dozen such studies at best that really explore in depth the nature of adult criminal activity.

${ }^{2}$ The Klockars volume is not without its own ambiguities (see Messinger, 1975:511, 512). 
uniformly, the evidence on criminal activity is flimsy (Gibbons, 1973; Reckless, 1973).

My second conclusion, more far reaching in its implications, is that we have almost totally neglected to examine those forms of crime and illegality that are likely to grow in importance in the modern world. We have neglected three different but related types of activity: first, the kinds of corporate illegality that were examined in Sutherland's original treatment of white-collar crime (Sutherland, 1949): second, those forms of criminal activity that gain increasing importance with changing technology and new ways of handling money, including stock manipulation, marketing of stolen securities, and forms of theft that depend on the computer and the credit card, as well as patterns of embezzlement described years ago in Donald Cressey's Other People's Money (1953); and third, perhaps most important and so far least examined, bribery or fraud, engaged in by public officials or by large-scale private entrepreneurs. It is in these areas that we have the most to learn. And here there can be no complaint that we have shifted our focus from the offender to the reaction system; we have been equally inattentive to both.

Lest there be any doubt about our neglect of the types of crime that typify an advanced, corporate, industrialized society, consider the following simple fact. The new two-volume Criminology Index (Wolfgang, Figlio, Thornberry, 1975), reviewing theoretical and empirical work in criminology from 1945 to 1972 , lists nearly 3700 books or articles. Of that total, only some 92 , or about 2.5 percent, deal with white-collar or corporate criminality, even when we include studies of organized crime as part of that total. If we remove them, and still use a relatively liberal and inclusive definition, no more than 1.2 percent of all the studies, articles, and writings deal with corporate crime, fraud, embezzlement, corruption, bribery, tax fraud or evasion, securities, stock manipulation, and the like. A review of Sociological Abstracts over the same period leads to a similar conclusion: most years over the past two decades yield no more than one article devoted to such topics. The most in any one year was nine in 1964, and most of those related to organized crime.

This is not to say that there is no interst in the subject, for virtually every text at least since the time of Sutherland's book has devoted a chapter to whitecollar crime or to crime in relationship to occupational groups. And one of our members has produced a thoughtful and intelligent collection of readings on the subject (Geis, 1968). What is perhaps most significant is that if one has read that collection of readings, along with Sutherland's original manuscript, one knows most of what is systematically known in our literature. It is a literature singularly lacking in freshness of insight and in new empirical inquiry. ${ }^{3}$

\footnotetext{
${ }^{3}$ One colleague, Irving L. Horowitz, feels that my characterization of the state of the literature is overdrawn, chiefly through failure to include important work by political scientists. See, for example, Nye (1967); Bayley (1966); Scott (1969); and Leff (1964). He may be correct, though I would note that most of the recent political science contributions have been restricted to the role of corruption in developing nations. Indeed, corruption has long been a theme of interest to political scientists (Key, 1934), though rarely has it gotten the same attention from sociologists, but see Chambliss (1976). In any event, were I rewriting this paper today I might well give it a different emphasis, because I have been devoting the last several months to the development of a program of research on white collar crime, with support from the Law Enforcement Assistance Administration. As part of the work on that grant, Susan Shapiro has produced a background paper on white-collar crime that has proven useful to us in clarifying many dimensions of the problem (Shapiro, 1976).
} 
But to conclude that this area is understudied and underresearched is to suggest three further questions: Is it truly important to study, or is it's neglect justifiable? If it is important, why have we neglected it? And finally, so what? What can we do about it? The remainder of my comments provide the beginnings of an exploration of these questions.

It is one thing to argue that our literature is systematically inattentive to an area of criminality; it is quite another to argue that such an omission is truly important. Perhaps it is simply more titillating to watch the mighty fall than to observe the poor or the inept in action. And, of course, it could be argued that relative to street crime, with its ever present danger of physical attack or the damage to limb and possible loss of life, corporate crime, bribery, self-dealing, fraud, and corruption have gotten just about the amount of attention they really deserve. Indeed, that is essentially the position taken in what is perhaps the most influential book affecting current criminal policy, political scientist James Q. Wilson's Thinking About Crime (1975). White-collar crime is dismissed in the short space of two sentences in an introduction. Surely that view represents, as Wilson notes, the conviction of most citizens. But we would be unwise, either as citizens or as sociologists, to share in that conviction.

Indeed, if we begin to look to the future rather than being rooted in the present and the immediate past, the importance of a shift in emphasis seems almost selfevident. First, there is a simple demographic factor, the change in the birth rate. Although the rising crime of the 1960 s cannot be attributed solely to the baby boom of the late 40 s and early $50 \mathrm{~s}$, it surely had much to do with it. Society is now aging, and the number of persons in the highest crime-committing categories for violent street crimes is shrinking and along with it, perhaps, our preoccupation with delinquency and youth crime. A second factor is some evidence of a decline in the use of heroin, surely a contributor to street crime, even though estimates of how large a contribution are difficult to make. ${ }^{4}$ Third, there are changes in the stratification structure in American society. The average level of education rises; there is an increase in real income, an increase in the number of white-collar workers, and a decline in the number of menial jobs.

Fourth, and critically important, is the enormous growth of regulatory processes as part of governmental social control. The growth of regulatory agencies is a central fact of our society, and the violation of rules of regulatory bodies looms increasingly large relative to common violations of criminal statutes. There is every reason to believe that illegality will increasingly take the form of violations of administrative rules, and that formal social control will be as much in the hands of regulatory agencies as in the hands of the police.

Fifth, and finally, there are signs that public definitions of deviance are beginning to shift in this direction. Not the least consequence of Watergate is the increased readiness on the part of many to doubt the credibility of those in high positions, and there is a greater readiness to look for deviance among those who

\footnotetext{
${ }^{4}$ In the cool reflection of hindsight, I am less certain of these first two observations than I was a year ago. There seems little doubt about the general trend in the birthrate, but it remains high among the poor, the black, and the uneducated, in other words, the very sectors of the population disproportionately represented in the official statistics on violent crime. What might be more appropriate would be to stress the potential polarization of types of crime, the one type characterizing the problems long associated with urban, lower class, slum and ghetto life, the other type white-collar violations of the kinds being addressed in this paper.
} 
run large organizations of almost any kind. Indeed, when a 21 st-century sociologist looks back to write about today's wayward Americans, as a former President of this Association once looked back to write about Wayward Puritans (Erikson, 1966), that 21 st-century scholar may be as likely to focus on deviations among those who manage the institutions of our society, on problems of fraud, bribery, and corruption of public trust, as on those street crimes that are currently perceived as virtually coextensive with "the crime problem."

Now the question immediately arises: if these subjects are so important, why have they been so neglected? Clearly, we know enough by now to avoid a naive assumption of a close correspondence between the objective importance of a problem, on the one hand, and the amount of resources devoted to its solution, on the other. To begin to answer questions about the systematic neglect of this area leads us, of course, into at least a modest version of the sociology of knowledge. Let me touch on some of the factors, even if briefly. For one thing, our official record-keeping system makes it much easier for us to study some things rather than others. The things that have been easy to study with regard to crime include those offenses regarded by the FBI as Part I offenses. As we shift from official criminal statistics to victimization studies and substitute the citizen for the police as initiators of crime statistics, we solve a number of problems, but we do not solve the problem of gathering data on white-collar and corporate criminal activity.

Another reason is that public and political definitions of the crime problem have guided funding organizations, and the funding has influenced the flow of research. The Law Enforcement Assistance Administration has been much more interested in violent crime than it has been in the kinds of offenses I have been discussing here, and it is not surprising, therefore, to find that research has followed their dollars.

Another factor is the traditional separation of academic sociology from the centers of economic activity. Except for a handful of sociologist related to business schools, another handful in other professional schools, and a third group, disparate and of unknown size, who come from wealth or who travel in circles that bring one close to corporate power and authority, we are typically far removed both ecologically, organizationally, and ideologically, from settings that would make it easy for us to learn more about such activities.

Of even greater importance, however, is the sheer difficulty of locating and organizing our inquiry so as to learn systematically and in detail about hidden activities. We are much better at doing street-corner studies than in getting behind closed doors. As the study of Vincent Swaggi (Klockars' pseudonym for his Professional Fence) indicates, it is difficult enough to gain access to someone involved in relatively traditional forms of criminal activity. How much more difficult is it likely to be among persons who live in a world of deceit and mistrust, and who are probably less likely than more traditional thieves to let a person inside their network, to reveal intimate knowledge, and to cooperate with a scientific investigator.

Finally, there is a degree of complexity to forms of organized criminal activity of the white-collar variety that may require a much longer period of training and preparation before observers are in a position to really make sense of the activity. Many of our richest monographs based on observational data have been Ph.D. dissertations with field work conducted by graduate students. It may be easier for them to follow drunks or ride in squad cars and impose themselves on citizens 
in the lower reaches of society than to enter the corridors of power, the securities offices, or the levels of corporate organizations where another kind of action is found.

For all these reasons, then, we should not be surprised at the imbalance in the direction of our empirical inquiries. But if the substantive problems themselves are as important as I believe them to be, we should not allow the organizational and other difficulties to stymie us but should set about to look for creative solutions to these various handicaps and barriers.

It is much easier to locate a domain for inquiry than it is to specify precisely which particular problems within that domain are strategically important to study. My first impulse is to say that the area is generally so barren that there is room for virtually any of the kinds of work we typically do, from ethnographic accounts of particular types of illegal activity, to social psychological studies of high-status offenders, to quantitative studies of the changing rates of fraud, security thefts, or SEC violations, to socio-historical studies of the emergence and functioning of such activity, and to public opinion studies of attitudes toward these forms of illegality relative to more traditional kinds. But $I$ hope we can be more systematic in our choice of problems than that implies. Indeed, it seems to me that we would do well to heed the words of an economist colleague of mine, who has written recently that we need to find ways "to bring to the task of project selection the same professional attention that has heretofore been given only to project execution" (Lindblom 1975). The patient and thoughtful examination and assessment that quotation implies has yet to be done.

However, in closing let me suggest tentatively some needs that strike me as critical ones. First, unlike some other areas of criminality, the basic motive behind all three of the types of activity I have been stressing-namely whitecollar crime, traditional but advanced forms of theft, and patterns of fraud, bribery and corruption-is economic gain, and we are likely to learn much about the activities in question if we can include economic analysis along with more traditional sociological inquiry.

A second and related point is that since many of the acts are based upon the rational analysis of gains versus costs, it would seem to be a natural testing ground for theories of deterrence; indeed much more so than more traditional forms of criminal activity. One could envision, for example, a broad series of studies designed to assess the relative effects of informal sanctions, formal economic sanctions, and jail or prison terms.

Third, there would seem to be particular value in focusing on social definitions with regard to the conduct in question. As the Norwegian sociologist Wilhelm Aubert pointed out many years ago, one of the fascinating features of whitecollar crime is the ambiguity of the moral judgments people make about it (1952). We have much to learn by focusing on those conceptions, on how they are shaped by the mass media, and on how information about illegal activity is controlled and structured so that some remain publicly invisible, while others become redefined as scandals.

Fourth, these kinds of illegality are often engaged in by organizations rather than individuals, and we should be able to design our inquiries so as to profit from and contribute to the understanding of organizational behavior.

Fifth, the interplay between the offender and the system and between the deviant and the agencies of social control is much more intimate in these areas than it is in more traditional forms of criminal activity. Our understanding of the 
relationship between violators and those who control them should be enhanced greatly by looking more closely at the regulatory process as it interacts with potential offenders. Indeed, Sutherland (1949) noted long ago, as have virtually all students of regulatory agencies since, the powerful voice those who are subject to regulation have in determining the rules that govern them. A related point is that, unlike most traditional property crimes, the information to be used in validating a charge of illegality or crime is typically in the hands of the very persons whose conduct is suspect. Thus we have, typically, not only questions of crime but questions of cover-up.

Sixth, it may be obvious to note that a large part of white-collar criminal activity, probably more so than normal street crime, involves collusion on the one hand and lying on the other. It provides a fertile ground for learning about the conditions of trust, for those who knowingly collaborate in illegal activity will have understandably strong needs to trust, or to know whether to trust. And similarly with respect to lying. Every form to be filled out for a government agency offers the possibility of lying. Our natural interest in presentations of self may be furthered by analysis of those illegal presentations represented by false or forged documents. We could use a good theory of lying and deceit.

Finally, I'd like to comment on the spirit underlying such an inquiry. We begin in ignorance. We don't know at this time the extent of crime and illegality of the type I have been referring to, its nature, or its social significance relative to street crime. We must approach it with the same combination of objectivity and empathy we try to bring to the study of the dispossessed. We must beware our biases. As John Kenneth Galbraith once noted, that the greatest critics of price tixing and other eftorts to limit competition and provide security were tenured university professors!

We may be aided in our efforts at empathic understanding by remembering that, though few of us wear white collars anymore, we still fall into that class from which white-collar criminals are drawn, and we must anticipate that the cold eye of science shall come to focus on us and our world too-from the student paper purchased rather than written, to plagiarism and theft of others' ideas, to fraud and negligence in the handling of research contracts.

It was just about a quarter of a century ago that the late Edwin $\mathrm{H}$. Sutherland published his little book on white-collar crime. So it is hardly an original idea to return to the topic and related issues even if my reasons for stressing it are different than his. But it is essential because so little has happened in the intervening years. It is necessary to urge that we redirect our attention from the petty thief to the corporate executive, from the offender who haunts the streets and alleys to those who inhabit the finer offices and restaurants, and from the police to the FTC, SEC, and IRS. Or perhaps I should not say redirect, for that implies that the problems of ordinary street crime and violent crime are unimportant. I intend no such implication, for their toll in human suffering is enormous. It is a matter of balance.

A former president of this association, Alvin Gouldner, once remarked that we have our palms up and our eyes down. Our palms may have to remain up, or at least out, since most of the research money comes from our own tax dollars. But it is long since time to raise our sights from those accused of being whores, thieves, drunks, derelicts, pimps, and hustlers-the study of those that have indelibly stamped our college social problems' classes as classes in "nuts, guts, 
and sluts"-to the more affluent but perhaps more acquisitive members who are located closer to the core of American society, and whose study may well tell us more about the kind of society we are to become.

\section{Aubert, Vilhelm \\ REFERENCES}

1952 "White-collar crime and social structure." American Journal of Sociology 58:263271.

Bayley, David H.

1966 "The effects of corruption in a developing nation." Western Political Quarterly 19:719-732.

Chambliss, William

1976 "The crime cabal," Unpublished manuscript.

Cressey, Donald R.

1953 Other People's Money. Glencoe: Free Press.

Erikson, Kai

1966 Wayward Puritans. New York: John Wiley and Sons.

Geis, Gilbert

1968 White Collar Criminal: The Offender in Business and the Professions. New York: Atherton Press.

Gibbons, Don C.

1973 Society, Crime and Criminal Careers: An Introduction to Criminology, second ed. Englewood Cliffs, New Jersey: Prentice-Hall.

Key, Valdimer Orlando, Jr.

1934 "The techniques of political graft in the United States." Ph.D. Dissertation, University of Chicago.

Klockars, Carl B.

1974 The Professional Fence. New York: Free Press.

Leff, Nathaniel $\mathbf{H}$.

1964 "Economic development through bureaucratic corruption." The American Behavioral Scientist 8:8-14.

Lindblom, Charles E. .

1975-Institution For Social and Policy Studies Bulletin. New Haven, Connecticut: 1976 Yale University, 12.

Messinger, Sheldon L.

1975 "The review of Carl Klockars' The Professional Fence." Journal of Criminal Law

Nye, J.S. and Criminology 66:511-512.

1967 "Corruption and political development: a cost-benefit analysis." American Political Science Review 61:417-427.

Quinney, Richard

1970 The Social Reality of Crime. Boston: Lit tle, Brown.

Reckless, Walter C.

1973 The Crime Problem, fifth ed. Englewood Cliffs, New Jersey: Prentice-Hall.

Scott, James C.

1969 "Corruption, machine politics, and political change." American Political Science Review 63:1142-1158.

Shapiro, Susan

1976 "A background paper on white collar crime: considerations of conceptualization and future research." Unpublished manuscript.

Sutherland, Edwin $\mathrm{H}$.

1937 The Professional Thjef. Chicago: University of Chicago Press.

1949 White Collar Crime. New York: Dryden Press.

Taylor, Ian, Paul Walton and Jock Young

1973 The New Criminology. New York: Harper and Row.

Thrasher, Frederick M.

1927 The Gang. Chicago: University of Chicago Press. 
Wolfgang, Marvin E., Robert M. Figlio, and Thorsten Sellin

1972 Delinquency in a Birth Cohort. Chicago: University of Chicago Press.

Wolfgang, Marvin E., Robert M. Figlio, and Terrence Thornberry

1975 Criminology Index 1945-1972. New York: Elsevier. 